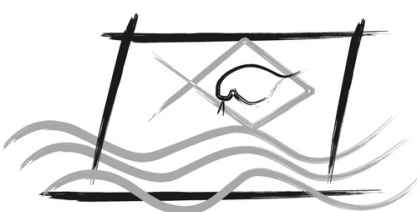

ECOTOX - BRASIL

\title{
Effect of sodium arsenite on liver function related enzymes of cat fish Heteropneustes fossilis and its chelation by zeolite
}

\author{
J. BALASUBRAMANiAn ${ }^{1} \&$ A. $\operatorname{KUMAR}^{2}$ \\ ${ }^{1}$ Assistant Professor, Department of Zoology, St. Thomas College, Bhilai, CG, India. \\ ${ }^{2}$ Associate Professor, Department of Zoology, Govt .V.Y.T.PG. Autonomous College, Durg, CG, India.
}

(Received March 26, 2013; Accept Septemper 04, 2013)

\begin{abstract}
Arsenic has been associated with a multitude of health problems and various works to study its impact on different organisms are being done in different parts of the world. Remediation of metal toxicity in environment and animal body including man is a controversial topic. Fishes accumulate the toxicant easily through food chain and water and transfer it to humans. In the present study the impact of arsenic on enzymes of the fish Heteropneustes fossilis and the ability of synthetic zeolite as chelating agent were carried out. The alteration in activities of GPT, GOT and Alkaline phosphatase in the liver of Heteropneustes fossilis and the chelating effect of synthetic zeolite on it was studied after exposure to different concentrations of sodium arsenite for different durations. Fishes are exposed to two different concentrations of sodium arsenite ( $200 \mathrm{~mL}$ and $400 \mathrm{~mL}$ of $1 \%$ solution), for 3 different durations (3days, 7days and 15 days). The activities of GPT $(\mathrm{F}=46.63>14.24)$ and ALP $(\mathrm{F}=595.33>190.97)$ was found significantly elevated along with increasing concentration of sodium arsenite. The reversal of the effect on treatment with $1 \%$ solution of zeolite, along with sodium arsenite (GPT, F=47.78 > 14.24; and ALP, F=562.33 > 190.97, at 5\% P) was reported. Where as the activity for GOT showed significant decrease $(\mathrm{F}=132.12>49.69$, at $5 \% \mathrm{P})$ on exposure to sodium arsenite and in this case also reversal of the effect on chelation with zeolite $(\mathrm{F}=107.21>49.69$, at $5 \% \mathrm{P})$, was noticed.
\end{abstract}

Keywords: Adsorption, chelation, Heteropneustes fossilis, liver enzymes, sodium arsenite, synthetic zeolite.

\section{INTRODUCTION}

Today arsenic is considered as a serious toxicant metallic pollutant of wide health concern and is indiscriminately available in ground water by natural way and in agricultural run off and mining process by anthropogenic way (Shalat et al., 1996). Arsenic has its source from ground water enriched with arsenic, arsenic containing pesticides, mining operations and agriculture run off (Chakraborty et al., 1998). Humans are largely being exposed to arsenic through underground water, agricultural output and industrial effluents.

Arsenic contamination and consequent ill health of people have been reported by many researchers. It is postulated that skin cancer, conjunctivitis, melanosis, hyperkeratosis, renal dysfunctions, hepatic and respiratory disorders and hematological alteration are common health problems caused by arsenic intoxication (Smith et al., 2000; Tseng, 1977). It is classified as a group A and category 1 human carcinogen by the USEPA (1997), and the international association of research on cancer, (IARC, 1987) respectively. It is suggested that the uptake of significant amounts of inorganic arsenic can intensify the chances of cancer development, especially skin cancer, lung cancer, liver cancer and lymphatic cancer (Bhattacharya et al., 2004). Chronic, long-term exposure to arsenic has been demonstrated to be carcinogenic in humans by Huang et al., (2004).

It has been reported that heavy metals affect various biochemical parameters of fish liver (Jana \& Bandyopadhyaya, 
1987). Arsenic induced biochemical changes in the liver tissues of freshwater fingerlings of fish Labeo rohita, was reported by Palaniappan \& Vijayasamudram (2009) using Fourier transform infrared (FTIR) spectroscopy. Enzymes are biochemical macromolecules that control metabolic process of organisms, thus a slight variation in enzyme activities would affect the organism by disturbing its metabolism (Roy, 2002; Humtsoe et al., 2007). The effect of chronic exposure of sodium arsenite on various biochemical parameters on different organs of the mammal Oryctolagus cuniculus was reported by Tripathi \& Kumar (2010).

The effect of arsenic on the activity levels of acid phosphatase, alkaline phospatase, glutamate-pyruvate transaminase and glutamate-oxaloacetate transaminase in muscles and liver tissues of the Carp, Labeo rohita were assessed by Humtsoe et al., (2007). It was reported that enzymatic activities were reduced and significant variation in the activities of these enzymes was noted after exposure to arsenic.

The zeolite $\left(\mathrm{M}_{2} / \mathrm{nO}^{-\mathrm{Al}_{2} \mathrm{O}_{3} \cdot \mathrm{xSiO}_{2} \cdot \mathrm{yH}} \mathrm{O}\right)$ comprises different elements and is an aluminosilicate mineral having special ability to carry water in their crystalline structure. They have a micro porous structure and are considered as effective adsorbent because of the ability to adsorb heavy metals from the contaminated water (Erdem et al., 2004). Zeolites are well known for their ion exchange capacity. The role of zeolites in the conversion of solid and liquid hazardous wastes into environmentally acceptable products has been demonstrated by Shevade et al., (2004). Several zeolites, namely clinoptilolite, chabazite, SZP1, 13X and 5A have been identified as potential candidates for arsenic removal from water. Synthetic zeolites are useful because of their controlled and known physicochemical properties relative to that for natural zeolites.

Faujasites are a class of synthetic zeolites that crystallizes in the cubic space group $\mathrm{Fd} 3 \mathrm{~m}$, with a lattice constant ranging from about 24.2-25.1 $\AA$, depending on the framework, aluminium concentration, cations, and state of hydration. There are 192 tetrahedral sites per unit cell. This zeolite is formed from 24-tetrahedra cuboctahedral units (sodalite cages), joined through hexagonal prisms (also known as double 6-rings), The structure can be viewed as the diamond structure, with the sodalite cages playing the role of carbon atoms, and the double 6-rings the role of $\mathrm{C}-\mathrm{C}$ bonds. The pore structure is characterized by super cages approximately $12 \AA$ in diameter, which are linked through windows about $8 \AA$ in diameter, composed of rings of 12 linked tetrahedrals. The structure is highly useful in catalytic applications because of specific cages and pores which can access quite large molecules. (Herreros, 1995; Meier et al., 1996; Kaduk \& Faber, 1995).

Zeolite $\mathrm{X}$ (higher $\mathrm{Al}$ ) and $\mathrm{Y}$ (lower $\mathrm{Al}$ ) are most common Faujasites of which $\mathrm{Y}$ is highly catalytic in nature and are synthesized in the $\mathrm{Na}$ form. The acid catalysis which is very common requires replacing the $\mathrm{Na}$ cation by protons and converting the sieve into the H-form (Kaduk \& Faber, 1995).

It has been observed that the $\mathrm{H}^{+}$and $\mathrm{NH}_{4}^{+}$forms of the synthetic zeolites were capable of removing arsenite to 50



Figure 1 - The faujasite structure, The larger hatched circles represent the tetrahedral "T" sites (Al or Si), and the smaller open circles indicate the oxygen positions (Adopted from:Kaduk \& Faber,1995).

ppb within 15 min, which is the current permitted maximum contaminant level (MCL) for arsenic in the United States (Shevade \& Ford, 2004). The fact that zeolite exchangeable ions are relatively innocuous (sodium, calcium, and potassium ions) makes them particularly suitable for removing undesirable heavy metal ions from industrial effluent waters. (Erdem et al., 2004; Jain, 1999).

In the present work the disturbance of metabolism in Heteropneustes fossilis on exposure to different concentrations of sodium arsenite for different durations and the ability of the synthetic zeolite, type $\mathrm{Y}$, for removing arsenic toxicity was found.

\section{MATERIALS AND METHODS}

The Teleost cat fish, Heteropneustes fossilis, was selected for experiment and were collected from local pond. The fishes selected for experiment were 7-8 inch of length and average weight of $125-150 \mathrm{gm}$. and were maintained in glass aquarium of $76.2 \mathrm{~cm} \times 45.72 \mathrm{~cm} \times 45.72 \mathrm{~cm}$ dimension, with $20 \mathrm{~L}$ of chlorine-free bore well water. The fishes selected for experiment were first acclimatized in the lab for 15 days under normal room temperature $\left(27-29^{\circ} \mathrm{C}\right), \mathrm{pH}-7.2-7.5$ and $\mathrm{DO}-6$ to $6.5 \mathrm{mgL}^{-1}$. The fishes were fed once daily with the fish food available in the market. The water was changed periodically.

The fishes were then divided into five experimental groups, each with 5 fishes. One group was kept for control set, and the remaining four for experimental sets. The test chemical selected for the experiment was obtained from SD Fine Chem. Ltd., Mumbai, India. Another test chemical selected as chelating agent was Zeolite (Type-Y, Sodium form), obtained from Hi-Media Laboratories Ltd., Mumbai, India.

The experimental group of five fishes were exposed to four different compositions of test solution, i.e. two doses $(200 \mathrm{~mL} \& 400 \mathrm{~mL}$ ) of $1 \%$ solution of sodium arsenite in 20 $\mathrm{L}$ water and two doses $(200 \mathrm{~mL} \& 400 \mathrm{~mL})$ of $1 \%$ solution of sodium arsenite along with $1 \%$ zeolite in $20 \mathrm{~L}$ water in a

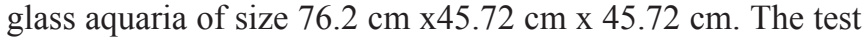


animals for all set of experiments were exposed with both test solutions for 3 days, 7 days and 15 days for evaluation of acute toxicity. The water of aquaria was changed daily for complete duration of experiment and physico-chemical parameters were maintained. For evaluation of toxicity by arsenic and chelating effect of zeolite, the parameters - GPT, GOT and ALP were selected.

After exposure to specific dose, all fishes were sacrificed. Liver tissue was taken out in test tubes, kept in ice cold water. The tissues were then homogenized using a glass homogenizer with 5\% trypsin. The homogenate was filtered through Watman No. 1 filter paper and then used for testing enzymatic activities. Estimation of activities of GOT \& GPT was done following Reitman and Frankel's method (1957) by End point reaction and ALP was estimated by visible kinetic reaction (Bowers \&McComb, 1966). Statistical analysis of the results was done by two way ANOVA, using the software Minitab.

\section{RESULT}

The toxic effects of arsenic on GPT, GOT and Alkaline phosphatise activity of Heteropneustes fossilis exposed to different doses of sodium arsenite and the chelating effect of zeolite were examined and the results were as below.

\section{Alteration in GPT activity}

The control value of SGPT activity from liver extract was found to be16.69 $\pm 3.39 \mathrm{UL}^{-1}$ and it was found decreased up to $12.22 \pm 0.81 \mathrm{UL}^{-1}$ after exposure of $200 \mathrm{~mL}$ of $1 \%$ sodium arsenite for 3days, but after exposure of $400 \mathrm{~mL} \mathrm{1 \%}$ sodium arsenite for same duration it was found increased up to $37.58 \pm 18.18 \mathrm{UL}^{-1}$. For 7 days exposure, the activity of SGPT was found increased up to $49.75 \pm 2.95 \mathrm{UL}^{-1}$ in response of 200 $\mathrm{mL}$ of sodium arsenite and up to $124.25 \pm 3.18 \mathrm{UL}^{-1}$ in response of $400 \mathrm{~mL}$ sodium arsenite. Similarly for 15 days exposure, it was found increased up to $58.80 \pm 5.79 \mathrm{UL}^{-1}$ in response of 200 $\mathrm{mL}$ and up to $28.14 \pm 0.22 \mathrm{UL}^{-1}$ in response of exposure to 400 $\mathrm{mL}$ sodium arsenite.

After chelation with zeolite, the value of GPT activity reported for 3days duration was $15.86 \pm 1.71 \mathrm{UL}^{-1}$ for 200 $\mathrm{mL}$ and $13.01 \pm 0.95 \mathrm{UL}^{-1}$ for $400 \mathrm{~mL}$ of the solution (sodium arsenite + zeolite). For 7 days exposure, the activity reported was $15.89 \pm 3.18 \mathrm{UL}^{-1}$ and $18.81 \pm 1.89 \mathrm{UL}^{-1}$, respectively on exposure to $200 \mathrm{~mL}$ and $400 \mathrm{~mL}$ of the solution. For 15 days exposure, the activity reported was $17.50 \pm 1.61 \mathrm{UL}^{-1}$ and $14.80 \pm 1.32 \mathrm{UL}^{-1}$, respectively for $200 \mathrm{~mL}$ and $400 \mathrm{~mL}$ of the solution.

The activity of GPT in liver of Hetropneustes fossilis exposed to sodium arsenite was found increased significantly $(\mathrm{p}<0.05)$, after exposure to doses, $200 \mathrm{~mL}$ and $400 \mathrm{~mL}$, for 7 days and 15 days duration each, in comparison to control group. But the activity of the enzyme decreased significantly $(\mathrm{p}<0.05)$ to normal range compared to control, after treatment with zeolite, for all exposures.

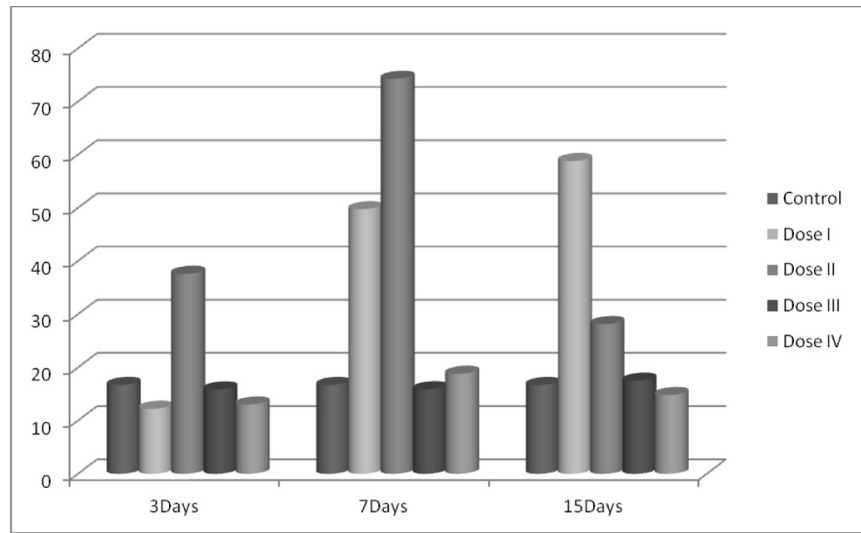

Dose I: Sod.arsenite (200ml); Dose II:Sod.arsenite (400ml); Dose III:Sod. arsenite+Zeolite(200ml); Dose IV:Sod.arsenite+Zeolite(400ml).

Figure 2 - Figure showing activity of GPT from liver of Heteropneustes fossilis on exposure to different concentrations of sodium arsenite and sodium arsenite + zeolite.

\section{Alteration in GOT activity}

The control value of GOT activity from liver extract was found to be $176.40 \pm 11.27 \mathrm{UL}^{-1}$ and it was found decreased to $12.22 \pm 1.56 \mathrm{UL}^{-1}$ after exposure of $200 \mathrm{~mL}$ of $1 \%$ sodium arsenite for 3 days and $35.00 \pm 9.56 \mathrm{UL}^{-1}$ after exposure of $400 \mathrm{~mL}$ of $1 \%$ sodium arsenite for the same duration. For seven days exposure, the activity was reported to be decreased to $27.94 \pm 5.45 \mathrm{UL}^{-1}$ in response of $200 \mathrm{~mL}$ and up to $17.03 \pm 5.13 \mathrm{UL}^{-1}$ in response of 400 $\mathrm{mL}$. Similarly for 15 days exposure, it was reported decreased to $92.69 \pm 4.61 \mathrm{UL}^{-1}$ in response of $200 \mathrm{~mL}$ and to $15.99 \pm 2.74 \mathrm{UL}^{-1}$ in response of $400 \mathrm{~mL}$ of sodium arsenite.

After chelation with zeolite, the value of GOT activity reported for 3days duration was $118.70 \pm 9.39 \mathrm{UL}^{-1}$ for $200 \mathrm{~mL}$ and $150.66 \pm 11.30 \mathrm{UL}^{-1}$ for $400 \mathrm{~mL}$ of the solution (sodium arsenite + zeolite). For 7 days exposure, the activity reported was $115.36 \pm 3.6 \mathrm{UL}^{-1}$ and $170.60 \pm 8.41 \mathrm{UL}^{-1}$, respectively for $200 \mathrm{~mL}$ and $400 \mathrm{~mL}$ of the solution. For 15 days exposure, the activity reported was $170.00 \pm 9.23 \mathrm{UL}^{-1}$ and $168.47 \pm 8.31 \mathrm{UL}^{-1}$, respectively for $200 \mathrm{~mL}$ and $400 \mathrm{~mL}$ of the solution.

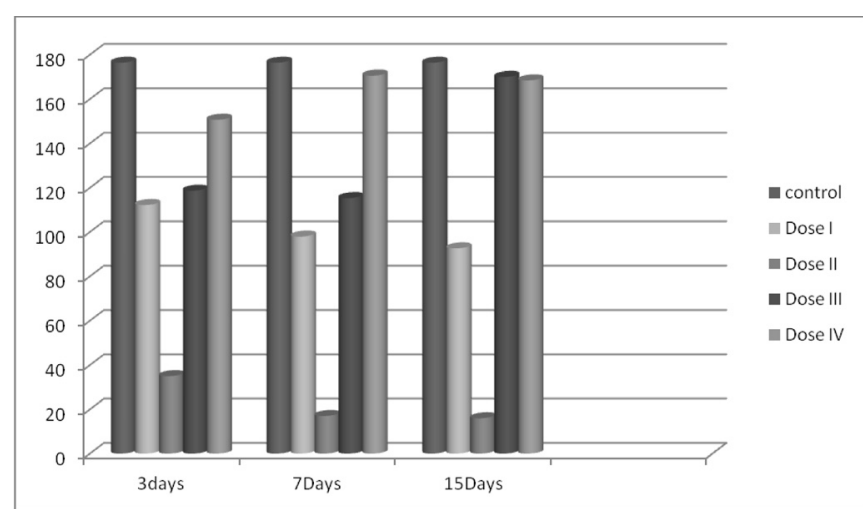

Dose I: Sod.arsenite (200ml); Dose II:Sod.arsenite (400ml); Dose III:Sod. arsenite+Zeolite(200ml); Dose IV:Sod.arsenite+Zeolite $(400 \mathrm{ml})$.

Figure 3 - Figure showing activity of GOT from liver of Heteropneustes fossilis on exposure to different concentrations of sodium arsenite and sodium arsenite + zeolite. 
The activity of GOT showed a significant decrease $(p<0.05)$ from control value on exposure to all doses of exposure to sodium arsenite. After treatment with zeolite along with sodium arsenite, an increase in the activity of GOT $(p<0.05)$ was observed, in comparison to control, especially with longer duration and higher concentration of the test solution.

\section{Alteration in Alkaline phosphatase activity}

Similarly, the control value for activity of Alkaline phosphatase from liver extract obtained was $22.00 \pm 3.94 \mathrm{UL}^{-1}$ and it was found increased to $41.20 \pm 7.56 \mathrm{UL}^{-1}$ after exposure of $200 \mathrm{~mL}$ of $1 \%$ sodium arsenite for 3 days and $74.20 \pm 6.65$ $\mathrm{UL}^{-1}$ after exposure of $400 \mathrm{~mL}$ of $1 \%$ sodium arsenite for the same duration. For seven days exposure, the activity was reported to be increased to $71.00 \pm 3.61 \mathrm{UL}^{-1}$ in response of $200 \mathrm{~mL}$ and up to $84.40 \pm 10.14 \mathrm{UL}^{-1}$ in response of 400 $\mathrm{mL}$ of sodium arsenite. Similarly for 15 days exposure, it was reported increased to $102.00 \pm 8.94 \mathrm{UL}^{-1}$ in response of $200 \mathrm{~mL}$ and to $93.40 \pm 40.35 \mathrm{UL}^{-1}$ in response of $400 \mathrm{~mL}$ of sodium arsenite.

After chelation with zeolite, the value of activity of Alkaline phosphatase reported for 3days duration was $67.60 \pm 13.88 \mathrm{UL}^{-1}$ for $200 \mathrm{~mL}$ and $31.20 \pm 1.30 \mathrm{UL}^{-1}$ for 400 $\mathrm{mL}$ of the solution (sodium arsenite + zeolite). For 7 days exposure, the activity reported was $42.00 \pm 3.17 \mathrm{UL}^{-1}$ and $22.60 \pm 11.44 \mathrm{UL}^{-1}$, respectively for $200 \mathrm{~mL}$ and $400 \mathrm{~mL}$ of the solution. For 15 days exposure, the activity reported was $74.00 \pm 1.58 \mathrm{UL}^{-1}$ and $31.80 \pm 1.19 \mathrm{UL}^{-1}$, respectively for 200 $\mathrm{mL}$ and $400 \mathrm{~mL}$ of the solution.

The activity of Alkaline phosphatase showed a significant increase $(p<0.05)$ for all set of exposures of the test chemical (sodium arsenite). On treatment with zeolite, the activity of the enzyme decreased significantly, for all set of exposures, in comparison to control $(p<0.05)$.In this experiment also it was observed that the decrease in the activity of the enzyme was more prominent on exposure to longer duration and higher concentration of the chelating agent.

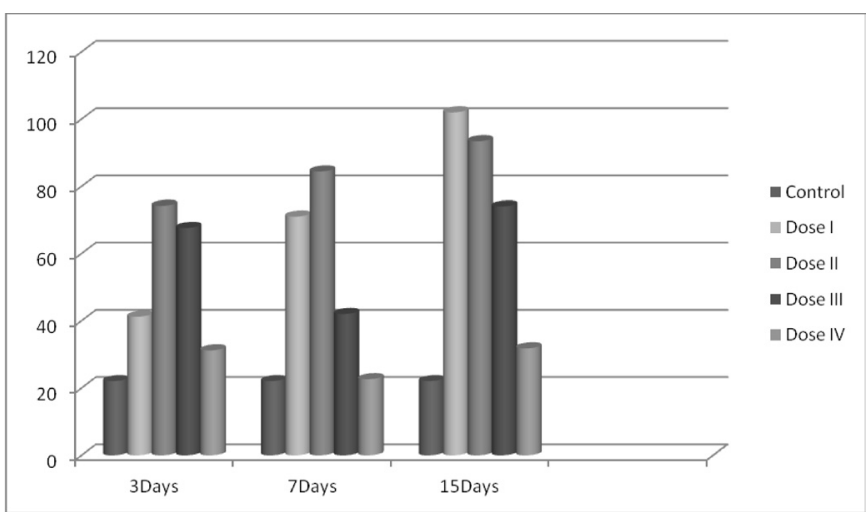

Dose I: Sod.arsenite (200ml); Dose II:Sod.arsenite (400ml); Dose III:Sod. arsenite+Zeolite(200ml); Dose IV:Sod.arsenite+Zeolite(400ml).

Figure 4 - Figure showing activity of Alkaline phosphatase from liver of Heteropneustes fossilis on exposure to different concentrations of sodium arsenite and sodium arsenite + zeolite.
The activity of GPT in liver of Hetropneustes fossilis exposed to sodium arsenite was found increased significantly $(\mathrm{F}=46.63>14.24)$,at $5 \% \mathrm{P}$, after exposure to doses, $200 \mathrm{~mL}$ and $400 \mathrm{~mL}$, for 7 days and 15 days duration, in comparison to control group. But the activity of the enzyme decreased significantly $(\mathrm{F}=47.78>14.24)$ to normal range compared to control, after treatment with zeolite, for all exposures.

The activity of GOT showed a significant decrease $(\mathrm{F}=132.12>49.69)$ from control value on exposure to sodium arsenite of all doses. But an increase in the activity of GOT $(107.21>49.69)$ was observed when the fishes were treated with zeolite.

At the same time, the activity of Alkaline phosphatase showed a significant increase $(\mathrm{F}=595>190.97)$ for all set of exposures of the test chemical to sodium arsenite. On treatment with zeolite, the activity of the enzyme decreased significantly, for all set of exposures, in comparison to control $(562.33>190.97)$ at $5 \% \mathrm{P}$.

\section{DISCUSSION}

In the experiments sodium arsenite was observed to cause significant $(\mathrm{P}<0.05)$ increase in the activity of GPT \& Alkaline phosphatase and decrease in the activity of GOT in the liver. These results suggested the inhibitory role played by arsenite in cellular metabolism. Addition of zeolite to arsenic contaminated media, significantly reduced $(\mathrm{P}<0.05)$ the metal level in water and making it less available to the animal, which in turn helped to improve the enzyme activity.

Several authors have reported increased activity of GPT and GOT in various animals under arsenic intoxication. Humtsoe et al., in 2007 have studied the effect of sodium arsenicum $\left(\mathrm{Na}_{2} \mathrm{HAsO}_{4} \cdot 7 \mathrm{H}_{2} \mathrm{O}\right)$ (with 96 and $144 \mathrm{mgL}^{-1}$ sub lethal concentration), on different enzymes of juvenile Labeo rohita, acclimatized in glass aquarium $(36 \times 24 \times 24 \mathrm{~cm})$ with constant physic-chemical conditions (oxygen-6.00-6.50 $\mathrm{mgL}^{-1}$, $\mathrm{pH}$ 7.2-7.5 and temperature $27-29^{\circ} \mathrm{C}$ ). After one month exposure they analysed activity of GOT, GPT, ACP and ALP and found significantly decreased activities for all enzymes at $144 \mathrm{mg} \mathrm{L}^{-1}$ concentration, but the activity of ACP and ALP was found profoundly decreased. The findings of Humtsoe et al. was affirmative to our finding for GOT but our finding differ from their finding for ALP and GPT.

In arsenic treated rabbit SGPT and SGOT activity was reported significantly increased by Ahmad in 2004. Islam et al., (2005) have reported significant increase in SGPT and SGOT activity in arsenic treated rat. In arsenic treated Swiss albino mice increased activity of SGPT, SGOT, ALP and ACP was also reported by Sharma et al. in 2007. Our findings were affirmative to the findings of the above scientists regarding the activity of ALP and GPT.

Roy in 2002 reported that the liver is major organ for removal of xenobiotics in fishes. Karatas and Kalay in 2002 have also attributed that different organic and inorganic chemicals adversely affects integrity of hepatic cell 
organelles and membrane transports which leads to alteration in metabolic pathways.

In 2007, Vutukuru et al., have also reported imbalance in hepatic enzyme activity in arsenic exposed Labeo rohita. They conducted experiment to evaluate toxic effect of both arsenic and hexavalent chromium on enzymatic activity of Labeo rohita and reported that there was a significant increase in the activity of hepatic enzyme ALT, however no such significant change was observed in chromium exposed fish and concluded ALT as biomarker for arsenic induced hepatotoxicity in Labeo rohita.

In present study changed enzymatic activity indicates damage to hepatic cells under intoxication of arsenic. It is also an established fact that arsenic toxicity causes oxidative stress and antioxidant enzymes like glutathione dependant enzymes act positively against arsenic for defence. A decrease in glutathione-s-transferase, glutathione peroxidise, glutathione reductase and catalase was observed by Allen and Rana in 2004 in arsenic exposed liver and kidney. This can be corelative with changed activity of GOT and GPT in test animal exposed to arsenic.

Jain et al., in 1999 have studied the protective role of zeolite in lead induced toxicity in Heteropneustes fossilis. In an experiment they found that 35 and 120 days exposure of sublethal doses of lead nitrate to Heteropneustes fossilis resulted in decrease in soluble protein, RNA and glycogen in liver and increase in serum cholesterol but the presence of zeolite in exposure solution decreased all the adverse effects. Although, literature related to arsenic removal by zeolite is not available but affinity of zeolite towards many toxic cations based on ion exchange with respect to precipitation was reported by several authors (Pansini et al., 1989: Jain et al., 1999).

Halimoon \& Yin (2010) reported that removal of heavy metals from textile waste water was effective using zeolite, Erdem et al., (2004) also reported that natural zeolites can be used effectively for the removal of metal cations from wastewater. Shevade \& Ford (2004) proved that NY6 zeolites were very effective for arsenic removal from polluted water.

Our finding is comparable with the findings observed in literature with regards to the alteration in activity of GPT, GOT and Alkaline phosphatase in animals exposed to arsenic and other heavy metals. The findings of the present study indicate that arsenic exposure is responsible for significant alteration in activity of GPT, GOT and Alkaline phosphatase in comparison to control in Heteropneustes fossilis and treatment with zeolite could significantly bring recovery of the conditions in the fish.

The efficacy of zeolites in reducing heavy metals, other than arsenic from animal body was evaluated by many studies. But chelating effect of zeolite for arsenic toxicity has not been properly examined. No literature is available for zeolite based chelation of arsenic from any animal body, that is why an attempt was made and significant result was found. We can conclude that like other heavy metals, arsenic toxicity may also be reduced from aquatic fauna by using zeolite. Further structural specification of zeolite and related efficacy of chelation of arsenic is yet to be established.

\section{REFERENCES}

AHMED, S. 2004. Effect of filtration of arsenic contaminated water and interaction of arsenic with few reagents in rabbit. MS Thesis, Dept. of Pharmacology, Bangladesh Agri. University, Bangladesh.

BHATTACHARYA, P., WELCH, A.H., AHMED, K.M., JACKS, G. \& NAIDU, R. 2004. Arsenic in ground waters of sedimentary aquifers. Appl. Geoch. 19(2): 163-260.

BOWERS, Jr G.N. \& McCOMB, R.B. 1966. A continuous spectrophotometric method for measuring the activity of serum alkaline phosphatase. Clin. Chem. 12:70-89.

CHAKRABORTY, D., SAMANTA, G., MANDAL, B.K, CHAUDHURY, T.R., CHANDA, C.R., BISWAS, B.K., DHAR, R.K., BASU, G.K. \& SAHA, K.C. 1998. Calcutta's industrial pollution: Ground water Arsenic contamination in residential area and sufferings of people due to industrial effluents discharge-An eight-year study report. Current Sc. 7(4): 346-360.

CHIOU, P.W., CHEN, K.L. \& YU, B. 1999. Effect of roxarsone on performance, toxicity, tissue accumulation and residue of eggs and excreta in laying hens. J. Sc. Food Agric. 74: 229-236.

DUBALE, M.S. \& SHAH, P. 1981. Biochemical alterations induced by cadmium in the liver of Channa punctatus. Envir. Res. 26: 110-118. http://dx.doi.org/10.1016/0013-9351(81)90189-4

ERDEM, E., KARAPINAR, N. \& DONAT, R. 2004. The removal of heavy metal cations by natural zeolites. J. Colloid Interface Sc. 280: 309-314. http://dx.doi:10.1016/j.jcis.2004.08.028.

HALIMOON, N. \& SOO YIN, R.G. 2010. Removal of heavy metals from textile wastewater using zeolite. Envir. Asia, 3(Special issue):24-130.

HERREROS, B. 1995. The X-Ray Diffraction Zeolite. Database. http://chemmac1.use.edu/bruno/ zeodat/Intro.html.

HUANG, C., KE, Q., COSTA, M. \& SHI, X. 2004. Molecular mechanismofarsenic carcinogenesis. Mol.Cell.Biochem. 255:5766. http://dx.doi.org/10.1023/B:MCBI.0000007261.04684.78

HUMTSOE, N., DAVOODI, R., KULKARNI, B.G. \& CHAVAN, B. 2007. Effect of arsenic on the enzymes of the Rohu Carp, Labeo rohita. Raffles Bul. Zool. 14:17-19.

IARC (International Agency for Research on Cancer), 1987. Arsenic and arsenic compounds, IARC monographs on the evaluation of carcinogenicity; updating of IARC monographs. 1-42. Lyon: IARC. 100 (suppl.7).

ISLAM, M.N., AWAL, M.A., RAHMAN, M.M., ISLAM, M.S., MOSTOFA, M. 2005. Effects of arsenic alone and in combination with selenium, iron and zinc on clinical signs, body weight and haematobiochemical parameters in long Evans rats. Bangladesh J. Vet. Med. 3: 75-77.

ISLAM, M.S., AWAL, M.A., MOSTOFA, M., BEGUM, F., KHAIR, A., MYENUDDIN, M. 2009. Effect of spirulina on biochemical parameters and reduction of tissue arsenic concentration in arsenic induced toxicities in ducks. Inter. J. Poultry Sc. 8 (1): 69-74. http://dx.doi.org/10.3923/ijps.2009.69.74

JAIN, S.K. 1999. Protective role of zeolite on short- and longterm lead toxicity in the teleost fish Heteropneustes fossilis. Chemosphere. 39(2): 247-251. http://dx.doi.org/10.1016/S00456535(99)00106-X

JANA, S. \& BANDYOPADHYAYA 1987. Effects of heavy metals on some biochemical parameters in the fresh water fish Channa punctatus. Envir. Ecol. 3:488-493. 
KARATAS, S. \& KALAY, M. 2002. Accumulation of lead in the gill, liver, kidney and brain tissues of Tilapia zilli. Turk. J. Vet. Anim. Sci. 26:471-477.

KADUK, J.A. \& FABER, J. 1995. Crystal structure of Zeolite $\mathrm{Y}$ as a function of ion exchange: Rigaku J. 12(2):14-34.

MEIER, W.M., OLSON, D.H. \& BAERLOCHER, CH. 1996. The Atlas of Zeolite Structure Types, $4^{\text {th }}$ edition, London. Elsevier, Zeolites. 17, 1-230.

PALANIAPPAN, P.L.R.M. \& VIJAYASUNDARAM, V. 2009. Effect of arsenic exposure and the efficacy of DMSA on the proteins and lipids of the gill tissues of Labeo rohita. Food Chem. Toxicol. 47(8):1752-1759. http://dx.doi.org/10.1016/j. fct.2009.04.016

PANSINI, M. \& COLELLA, C. 1989. Lead pollution control by zeolite. Mat. Eng. 1:623-630.

REITMAN, S. \& FRANKEL, S. 1957. A colorimetric method for the determination of serum glutamic oxaloacetic and glutamic pyruvic transaminases. Am. J. Clin. Pathol. 28:56-63.

ROY, S.S. 2002. Some toxicological aspects of Chloropyrifos to the intertidal fish Boleopthalmus dussumieri. Ph D Thesis, University of Mumbai, India. 52-71.

SHALAT, S.L., WALKER, D.B. \& FINNELL, R.H. 1996. Role of arsenic as a reproductive toxin with particular attention to neural tube defects. J. Toxicol. Environ. Health. 48: 253-272. http:// dx.doi.org/10.1080/009841096161320

SHARMA, A., SHARMA, M.K. \& KUMAR, M. 2007. Protective effect of Mentha piperita against arsenic induced toxicity in liver of Swiss albino mice. Basic Clin. Pharmacol. Toxicol. 100:249257. http://dx.doi.org/10.1111/j.1742-7843.2006.00030.x

SHEVADE, S. \& FORD, R.G. 2004. Use of synthetic zeolites for arsenate removal from pollutant water: Water Res. 38:31973204. http://dx.doi.org/10.1016/j.watres. 2004.04.026.

SMITH, A.H., ARROYO, A.P. \& MAZUMDAR, D.N. 2000. Arsenic-induced skin lesions among Atacameno people in northern Chile despite good nutrition and centuries of exposure. Environ. Health Perspect. 108: 617-620.

TRIPATHI, S. \& KUMAR A. 2010. Effect of acute and chronic exposure of sodium arsenite $(\mathrm{Na} 3 \mathrm{AsO} 3)$ on total protein, albumin, and globulin in serum of Oryctolagus cuniculus L., Toxicol. Environ. Chemistry, 1-7, iFirst. http://dx.doi.org/10.10 80/02772248.2010.508611

TSENG, W.P. 1977. Effects and dose response relationships of skin cancer and black foot disease with As. Environ. Health Perspect. 19: 109-119.

USEPA IRIS, 1997. (Integrated Risk Information System) on line data base maintained in Toxicology Data Network (TOXNET) by the National Library of Medicine, Bethesda, Maryland.

VUTUKURU, S.S., PRABHATH, N.A., RAGAVERDER, M. \& YERAMILLI, A. 2007.Effect of arsenic and chromium on the serum aminotransferases activity in the Indian major carp, Labeo rohita. Int. J. Environ. Res. Public Health, 4: 224-227. http:// dx.doi.org/10.3390/ijerph2007030005 